Egypt. Acad. J. Biolog. Sci., 5(2): 29-34 (2013)

Email: egyptianacademic@yahoo.com

Received: 25 / 4 / 2013
C. Physiology \& Molecular Biology

ISSN: 2090-0767

www.eaibs.eg.net

\title{
Effect of renal dialysis on some haematological, electrolytes and biochemical parameters in hepatitis patients.
}

\author{
El-Zawhry, E. I. ${ }^{1}$; Salem, M. M. ${ }^{1}$; Abdel-Rached, G. H. ${ }^{1}$; Wafeek, M. ${ }^{2}$; \\ Galal, M. S. ${ }^{3}$ and Mohamed, E. E. T. ${ }^{1}$ \\ 1- Department of Zoology, Faculty of Science, Al-Azhar University. \\ 2- Central Laboratory for Aquaculure Research, Agriculure Research Center. \\ 3- Endoscopy Faculty of Medicine, Zagazig Unversity. \\ Email: marawan217@yahoo.com
}

\begin{abstract}
The present study was designed to finding the influence of renal dialysis in some haematological, electrolytes and biochemical parameters in kidney failure and kidney failure with hepatitis patients $(\mathrm{C}$ and $\mathrm{B})$ virus. The experiment was designed from ten normal healthy patients as control group and sixty male human patients were selected from hospital campus of the Zagazig University conducting adialysis three time aweek and classified according to dialysis into two major groups, the first group: patients with less than one year of dialysis. The second group: patients with more than one year of dialysis. Each group are divided into three sub groups are renal failure, renal failure with hepatitis c virus (HCV) and renal failure with hepatitis B virus (HB), asignificant decrease was recorded in RBCs count, $\mathrm{Hb}, \mathrm{HCt}$ and platelets count, also asignificant decrease was showed in serum sodium and calcium levels, while asignificant increase was demonstrated in WBCs count, serum potassium, phosphorus levels and transaminases (ASAT and ALAT) enzymes activities in patients with renal failure and renal failure with hepatitis $(\mathrm{C}$ and $\mathrm{B})$ virus .
\end{abstract}

Keywords: Renal failure, Hemodialysis, Hepatitis, Electrolytes, Kidney function and Liver function.

\section{INTRODUCTION}

Renal function as indicated by glomerular filtration rate (GFR) is associated with an increased mortality risk in patients with end stage renal disease (ESRD) on dialysis. Preventing or delaying the full loss of (GFR) can improve survival in dialysis patients. This supports the importance that is given to the effect of treatment options for patients with (ESRD) on the rate of decline of the residual renal function. (Willem et al., 2011).

Mhawech and Saleen (2000) reported that platelet dysfunction is often observed with chronic renal failure or liver disease in patients experiencing avariety of myeloproliferative and lymphoproliferative disorders.

Anaemia is the most common haematological Abnormalities in chronic renal failure. Also anaemia is recognized relatively early in the course of kidney dysfunction (Asort et al., 2002). Renal anaemia causes high sympathetic nerve activity abd linked to cardiovascular complacations, sush as increased blood pressure and left ventricular hypertrophy. (Ayus et al., 2005).

Carru et al., (2005) found adecrease in white blood cells count during hemolysis and it was investigation as function of different dialysis membranes.

Sankara et al. (2005) showed that the control of serum phosphste levels on patients with hemodialysis requires the restriction of dietary (po4) intake. The dose of (po4) binder ideal should be proportional to the amount of phosphorus ingested with each meal. While, Segal et al. (2008) found that hyperphosphatemia is among the most commom metabolic 
complications of the end stage renal dialysis.

Both hypokalemia and hyperkalemia are life threatening to hemodialysis patients. Hypokalemia haemodialysis patients with lower serum albumin. pre albumin showed amalnutrition and inflammatory status and caused increased mortality rate (Tyh et al., 2011).

Lemos et al. (2008) found that $\mathrm{HCV}$ infected patients had significantly higher serum ALT levels. While, Azevedo et al. (2007) reported that HCV infected patients with chronic renal failure (CRF) submitted for hemodialysis (HD) have lower serum ALT levels.

Dina et al. (2010) found that patients under going chronic hemodialysis, as well as hemodialysis staff members increase risk of infection with $\mathrm{HBV}$, that may be transmitted in the dialysis setting throught blood transfusions.

\section{MATERIALS AND METHODS Experimental design:}

The normal healthy control group ten subjects (human) and sixty male human patients are selected from the hospital campus of the Zagazig University conducting adialysis three times aweek and classified according to dialysis into two major groups:

The first group: Patients less than one year of dialysis.

The second group: Patients more than one year of dialysis.

Each group including 30 patients and divided into three subgroups, the first renal failure (20) patients, renal failure with HCV virus (20) patients and renal failure with HB virus (20) patients .Blood samples were taken after the dialysis process for aperiod of three months from the beginning of analysis, Samples were taken every two weeks for each patients taking the average of their results. Blood samples were taken with anticoagulant for haematological measurements. Also blood samples were taken without anticoagulant and centrifuge for 20 minutes at $3000 \mathrm{rpm}$ to obtained serum which separated for biochemical analysis.

\section{Biochemical analysis:}

Serum electrolytes were estimated according to the method of (Teitz, 1986). Using Chiron diagnostics kits.

Serum aspartate transaminase (ASAT) and alanine transaminase (ALAT) enzymes activities were estimated according to the method of (Reitman and Frankel, 1957) using biomereux kits.

\section{Statistical analysis}

Statistical analysis of the obtained data was done according to (Armitage, 1974) using $\mathrm{T}$ - test value.

\section{RESULTS}

Obtained data in table (1) showed a significant decrease $(\mathrm{P}<0.05)$ and $(\mathrm{P}<0.01)$ in RBCs count, $\mathrm{Hb}$ concentration, $\mathrm{HCt}$ values and platelets count in patients infected with renal failure and renal failure with hepatitis $(\mathrm{C}$ and $\mathrm{B}$ ) virus at the two different periods less and more than one year of dialysis. On the other hand a significant increase $(\mathrm{P}<0.01)$ in white blood cells count in patients infected with renal failure and renal failure with hepatitis (C and $\mathrm{B}$ ) virus at the two different periods less and more than one year of dialysis incomparison with the healthy patients.

Data in table (2) exhibited a significant decrease $(\mathrm{P}<0.05)$ and $(\mathrm{P}<0.01)$ in serum sodium and calcium levels in patients infected with renal failure and renal failure with hepatitis $(\mathrm{C}$ and $\mathrm{B}$ ) virus at the two different periods less and more than one year of dialysis, except group infected with renal failure in period less than one year of dialysis showed insignificant decrease in serum sodium level when compared with the control group. Also insignificant decrease in serum calcium level was 
recorded in patients infected with renal failure more than one year of dialysis.

Serum potassium and phosphorus levels observed a significant increase
$(\mathrm{P}<0.01)$ in all groups at two different periods less and more than one year of dialysis when compared with the healthy group.

Table 1: Means level of some haematological measurements in renal failure patients and renal failure infected with hepatitis $(\mathrm{C}$ and $\mathrm{B})$ virus at two different dialysis periods.

Prob. $\quad=$ Probability

N. S. = Non significant

\begin{tabular}{|c|c|c|c|c|c|c|c|c|}
\hline \multicolumn{3}{|c|}{ Periods } & \multicolumn{3}{|c|}{ Duration of dialysis less than one year } & \multicolumn{3}{|c|}{ Duration of dialysis more than one year } \\
\hline \multicolumn{2}{|l|}{ Parameter } & Control & $\begin{array}{l}\text { Renal } \\
\text { failure }\end{array}$ & $\begin{array}{c}\text { Renal } \\
\text { failure } \\
\text { with } \mathrm{HCV}\end{array}$ & $\begin{array}{c}\text { Renal failure } \\
\text { with HB }\end{array}$ & $\begin{array}{l}\text { Renal } \\
\text { failure }\end{array}$ & $\begin{array}{l}\text { Renal failure } \\
\text { with HCV }\end{array}$ & $\begin{array}{c}\text { Renal failure } \\
\text { with } \mathrm{HB}\end{array}$ \\
\hline \multirow{3}{*}{$\begin{array}{c}\mathrm{RBCs} \times 10^{6}, \\
\text { Cell } / \mathrm{mm}^{3}\end{array}$} & Mean & 4.72 & 3.76 & 4.02 & 3.60 & 3.68 & 3.89 & 3.78 \\
\hline & \pm S.D & 0.35 & 0.83 & 0.63 & 0.76 & 0.77 & 0.63 & 0.93 \\
\hline & Prob. & - & $\mathrm{P}<0.01$ & $\mathrm{P}<0.01$ & $\mathrm{P}<0.01$ & $\mathrm{P}<0.01$ & $\mathrm{P}<0.01$ & $\mathrm{P}<0.01$ \\
\hline \multirow{3}{*}{$\begin{array}{c}\text { WBCs x 10 } \\
\text { Cell } / \mathrm{mm}^{3}\end{array}$} & Mean & 7.23 & 9.71 & 10.01 & 10.33 & 10.57 & 11.09 & 10.56 \\
\hline & \pm S.D & 1.70 & 0.63 & 0.78 & 0.75 & 0.83 & 0.69 & 0.98 \\
\hline & Prob. & - & $\mathrm{P}<0.01$ & $\mathrm{P}<0.01$ & $\mathrm{P}<0.01$ & $\mathrm{P}<0.01$ & $\mathrm{P}<0.01$ & $\mathrm{P}<0.01$ \\
\hline \multirow{3}{*}{$\mathrm{Hb}, \mathrm{g} / \mathrm{dl}$} & Mean & 13.36 & 10.28 & 10.47 & 10.66 & 8.85 & 8.82 & 8.10 \\
\hline & \pm S.D & 1.21 & 0.91 & 0.47 & 1.31 & 0.80 & 0.56 & 1.00 \\
\hline & Prob. & - & $\mathrm{P}<0.01$ & $\mathrm{P}<0.01$ & $\mathrm{P}<0.01$ & $\mathrm{P}<0.01$ & $\mathrm{P}<0.01$ & $\mathrm{P}<0.01$ \\
\hline \multirow{3}{*}{ Hct, \% } & Mean & 41.1 & 35.7 & 35.9 & 31.8 & 28.8 & 29.06 & 24.9 \\
\hline & \pm S.D & 3.97 & 5.65 & 5.33 & 6.30 & 3.17 & 3.26 & 4.28 \\
\hline & Prob. & - & $\mathrm{P}<0.05$ & $\mathrm{P}<0.05$ & $\mathrm{P}<0.01$ & $\mathrm{P}<0.01$ & $\mathrm{P}<0.01$ & $\mathrm{P}<0.01$ \\
\hline \multirow{3}{*}{$\begin{array}{l}\text { Platelets x } 10^{3} \text {, } \\
\qquad / \mathrm{mm}^{3}\end{array}$} & Mean & 307.4 & 186.5 & 169.8 & 190.60 & 118.00 & 177.90 & 137.10 \\
\hline & \pm S.D & 40.92 & 66.89 & 71.10 & 30.80 & 29.41 & 70.93 & 43.10 \\
\hline & Prob. & - & $\mathrm{P}<0.01$ & $\mathrm{P}<0.01$ & $\mathrm{P}<0.01$ & $\mathrm{P}<0.01$ & $\mathrm{P}<0.05$ & $\mathrm{P}<0.01$ \\
\hline
\end{tabular}

$$
\begin{array}{ll}
\mathrm{P}<0.05 & =\text { significant }(*) \\
\mathrm{P}<0.01 & =\text { Highly significant }(* *)
\end{array}
$$

Table 2: Means level of some serum electrolytes in renal failure patients and renal failure infected with hepatitis $(\mathrm{C}$ and $\mathrm{B})$ virus at two different dialysis periods.

$$
\begin{array}{ll}
\text { Prob. } & =\text { Probability } \\
\text { N.S. } & =\text { Non significant } \\
\mathrm{P}<0.05 & =\text { significant }(*) \\
\mathrm{P}<0.01 & =\text { Highly significant }(* *)
\end{array}
$$

\begin{tabular}{|c|c|c|c|c|c|c|c|c|}
\hline \multicolumn{3}{|c|}{ Periods } & \multicolumn{2}{c|}{ Duration of dialysis less than one year } & \multicolumn{2}{c|}{ Duration of dialysis more than one year } \\
\hline \multicolumn{2}{|c|}{ Groups } & Control & $\begin{array}{c}\text { Renal } \\
\text { failure }\end{array}$ & $\begin{array}{c}\text { Renal } \\
\text { failure } \\
\text { with HCV }\end{array}$ & $\begin{array}{c}\text { Renal } \\
\text { failure } \\
\text { with HB }\end{array}$ & $\begin{array}{c}\text { Renal } \\
\text { failure }\end{array}$ & $\begin{array}{c}\text { Renal } \\
\text { failure } \\
\text { with HCV }\end{array}$ & $\begin{array}{c}\text { Renal } \\
\text { failure } \\
\text { with HB }\end{array}$ \\
\hline $\begin{array}{c}\text { Parameters } \\
\text { Sodium, }\end{array}$ & Mean & 140.8 & 137.7 & 135.8 & 133.3 & 132.2 & 130.5 & 131.9 \\
& \pm S.D & 4.05 & 6.48 & 4.78 & 6.12 & 3.85 & 7.12 & 5.10 \\
& Prob. & - & N. S & $\mathrm{P}<0.05$ & $\mathrm{P}<0.01$ & $\mathrm{P}<0.01$ & $\mathrm{P}<0.01$ & $\mathrm{P}<0.01$ \\
\hline Potassiu & Mean & 4.10 & 5.12 & 5.74 & 5.13 & 5.34 & 5.87 & 5.54 \\
m, & \pm S.D & 0.14 & 0.50 & 0.84 & 0.11 & 0.30 & 0.65 & 0.48 \\
mEq/L & Prob. & - & $\mathrm{P}<0.01$ & $\mathrm{P}<0.01$ & $\mathrm{P}<0.01$ & $\mathrm{P}<0.01$ & $\mathrm{P}<0.01$ & $\mathrm{P}<0.01$ \\
\hline Calcium & Mean & \pm .51 & 8.57 & 8.35 & 8.55 & 8.85 & 8.85 & 8.38 \\
mg/dl, & Prob. & 0.61 & 0.61 & 0.52 & 0.76 & 0.70 & 0.54 & 0.74 \\
& & - & $\mathrm{P}<0.01$ & $\mathrm{P}<0.01$ & $\mathrm{P}<0.01$ & $\mathrm{~N} . \mathrm{S}$ & $\mathrm{P}<0.05$ & $\mathrm{P}<0.01$ \\
\hline Phosphor & Mean & 3.99 & 7.29 & 7.82 & 7.77 & 5.00 & 5.44 & 5.30 \\
-us, & \pm S.D & 0.41 & 0.98 & 0.83 & 0.87 & 0.56 & 0.48 & 0.37 \\
mg/dl & Prob. & - & $\mathrm{P}<0.01$ & $\mathrm{P}<0.01$ & $\mathrm{P}<0.01$ & $\mathrm{P}<0.01$ & $\mathrm{P}<0.01$ & $\mathrm{P}<0.01$ \\
\hline
\end{tabular}

A significant increase $(\mathrm{P}<0.01)$ in hepatitis $(\mathrm{C}$ and $\mathrm{B})$ virus throughtout the serum transaminases (ASAT and ALAT) experimental periods less and more than enzymes activities in patients infected one year of dialysis incomparison with with renal failure and renal failure with the control group (Table 3). 
Table 3: Means level of serum transaminases enzymes activities in renal failure patients and renal failure infected with hepatitis $(\mathrm{C}$ and $\mathrm{B})$ virus at two different dialysis periods.

\begin{tabular}{|c|c|c|c|c|c|c|c|c|}
\hline \multicolumn{3}{|c|}{ Periods } & \multicolumn{2}{c|}{ Duration of dialysis less than one year } & \multicolumn{3}{c|}{ Duration of dialysis more than one year } \\
\hline \multicolumn{2}{|c|}{ Groups } & Control & $\begin{array}{c}\text { Renal } \\
\text { failure }\end{array}$ & $\begin{array}{c}\text { Renal } \\
\text { failure } \\
\text { with HCV }\end{array}$ & $\begin{array}{c}\text { Renal } \\
\text { failure } \\
\text { with HB }\end{array}$ & $\begin{array}{c}\text { Renal } \\
\text { failure }\end{array}$ & $\begin{array}{c}\text { Renal } \\
\text { failure } \\
\text { with HCV }\end{array}$ & $\begin{array}{c}\text { Renal } \\
\text { failure } \\
\text { with HB }\end{array}$ \\
\hline ASAT, & Mean & 22.9 & 32.8 & 37.7 & 45.1 & 47.7 & 51.5 & 50.4 \\
u/L & \pm S.D & 7.26 & 2.89 & 4.49 & 4.14 & 4.02 & 3.92 & 3.59 \\
\hline ALAT, & Prob. & - & $\mathrm{P}<0.01$ & $\mathrm{P}<0.01$ & $\mathrm{P}<0.01$ & $\mathrm{P}<0.01$ & $\mathrm{P}<0.01$ & $\mathrm{P}<0.01$ \\
u/L & Mean & 21.7 & 52.6 & 55.0 & 53.9 & 61.2 & 63.8 & 60.6 \\
& I S.D & 3.26 & 4.27 & 4.24 & 2.99 & 3.22 & 4.80 & 2.49 \\
\hline
\end{tabular}

Prob. $\quad=$ Probability

N.S. $\quad=$ Non significant

P. $<0.01=$ Highly significant $(* *)$

\section{DISCUSSION \\ Haematological measurements}

In patients with end stage renal failure, serum erythropoietin (EPO) may increase after hepatitis $\mathrm{C}$ and $\mathrm{B}$ infection, resulting in an improvement of red cells status.

Radovic et al., 1999. Aaemia is the most common haematological abnormality in chronic renal failure (Asort et al., 2002).

Obtained results refere to decrease in red blood cells (RBCs) count, haemoglobin $(\mathrm{Hb})$ concentration, haematocrit $(\mathrm{HCt})$ values and platelets count in patient infected with renal failure and renal failure infected with hepatitis (C and $B$ ) virus these decrease maybe due to decrease dose of erythropoiesis stimulating agents with adequacy of dialysis or anaemia due to chronic kidney disease (Katzarski et al., 1999)

\section{Electrolytes}

In the present study the obtained results of serum sodium level recorded asignificant decrease, this decrease may be due to impaired renal capacity to excrete solute free water. This results are in agreement with (Agrawal et al., 2008) found that hyponatremia and hypernatremia represented disorders of water balance, or due to impaired renal water excretion and antidiuretic hormones (ADH) play an important role in hyponatremia .

Serum potassium level revealed asignificant increase in patients infected with renal failure and renal failure with hepatitis, these increase may be due to arise from true excess or imbalance in the distribution between potassium inside and outside of cells. Data found in the presented study showed asignificant decrease in serum calcium level, these decrease may be due to decrease renal tubular reabsorption of calcium causing decrease in calcium ion level these results are in agreement with (Kinder and Stewart., 2002) found that hypocalemia and decrease glomerular filteration rate lead to reduction in filtered calcium and increase in proximal tubular reabsorption of sodium and calcium these results are dis agreement with (Bilezikan et al., 2002). Hypophosphatemia as an independent risk factor for cardiovascular disease and mortality on dialysis or due to progressive deterioration in kidney function (Nagano et al., 2003).

\section{Transaminases}

Serum transaminases enzymes (ASAT and ALAT) revealed asignificant increase activities in patients infected with renal failure and renal failure with hepatitis ( $\mathrm{C}$ and $\mathrm{B})$ virus, these increase due to liver disease on long term dialysis. These results are in agreement with Hung 
et al. (1997) found that AST and ALT levels were higher in the positive HBV marker group.

Mohamed and Atta (2010) reported that hepatitis $\mathrm{C}$ infection is known to have ahigher prevalence of some components of metabolic syndrome and to be associated with chronic renal disease and disagreement with Azevedo et al. (2007) showed that HCV infected patients with chronic renal failure submitted with haemodialysis have lower ALT levels.

\section{REFERENCES}

Agrawal, M.; Shashank, R. and Joshi, A. K. (2008): Hyponatremia and hypernatremia disorders of water balance. Am. J. Physiol. Endo. Met., 286: $136-143$.

Armitage, P. (1974): Statistical methods in medical research. Black Well Scientific Pub. Oxford, London: pp. 116-120.

Asort, B. C.; Muntner, P.; Levin, A.; Eustace, J. A. and Coresh, J. (2002): Association of kidney function with anaemia the third national health and nutrition examination survey (19881994). Arch. Intern. Med., 162: 1401-1408.

Ayus , J.C.; Go, A. S. and Valderrabano, F. (2005): Effects of erythropoietin on left ventricular hypertrophy in adults with severe chronic renal failure and haemoglobin $<10 \mathrm{~g} / \mathrm{dl}$. Kidney, Int., 68 (2): 788-795

Azevedo, H. A.; Villela, C. A.; Perez, R. M.; Segadas, J. A. and Takahashi, C. (2007): Similar HCV viral load levels and genotype distribution among end stage renal dialysis patients on hemodialysis and HCV infected patients with normal renal function . J. Nephrol ., 20 : 609 -616.

Bilezikian, J. P.; Birken, S.; Beychok, S.; Schattner, A.; Gilad, A. and Cohen, J. (2002): Four patients receving chronic hemodialysis in systemic granulomatosis. Soc. Nephrol., 86: $1225-1233$.

Carru, C.; Deiana, L.; Sotgia, S.; Usai, M. F. and Zinellu, A. (2005): Relationship between white blood cells count and levels of serum haemocystine and cystine in healthy subjects. N. Engl. J. Med., 90(1): 136-139.

Dina, S.; Rasha, A.; Nihal, A.; Hala, T. and Sayed, A. (2010): Hepatitis B virus DNA in serum of hepatitis B surface antigen negative hemodialysis patients. J. Clin. Virol., 10:4081-4088.

Jyh, C. H.; Charn, T. W.; Chien, A. C. and Hung, C. (2011): Hypokalemia is associated with increase mortality rate in chronic hemodialysis patients. Blood Purif. 32: 254 -261.

Katzarski, K. S.; Charra, B. and Luik, A. J. (1999): Fluid state and blood pressure control in patients treated with long and short dialysis. Nephrol. Dial. Transplant., 14: 369-375.

Kinder, B.K. and Stewart, A. F. (2002): Patients on haemodialysis may develop severe and Symptomatic hypercalcemia if skeletal buffering is inffective. Clin. J. Am. Soc. Nephro., 39: 354- .

Lemos, M. F.; Longui, C. A. and Moreira, R. C. (2008): Hepatitis C in chronic kidney disease: predialysis patients more severe histological liver injury than hemodialysis patients. Am. Nephrol., 27(2):191-196.

Mhawech, P. and Saleem, A. (2000): Inherited gaint platelet disorders: classification and literature review. Am. J. Clin. Pathol., 113:176-190.

Mohamed,G. and Atta, M. D. (2010): Hepatitis virus infection (HBV and $\mathrm{HCV}$ ) in eleven Japanese hemodialysis units. Clin. Nephrol., 38:36-43.

Nagano, N.; Miyata, S.; Obana, S.; Kobayashi, N.; Fukushima, N., Burke, S. K. and Wada, M. (2003): Sevelamer hydrochloride, aphosphate 
binder, protects against deterioration of renal function in rats with progressive chronic renal insufficiency. Nephrol. Dial. Transplant., 18: 2014 - 2023.

Radovic, M.; Jelkmann, W.; Djukanovic, L. and Ostric, V. (1999): Serum erythropoietin and interleukin-6 levels in haemodialysis Patients with hepatitis virus infection. J. Interferon Cytokine Res. Apr., 19(4): 369-373.

Reitman, S. and Frankel, S. (1957): A colourimetric method for determination of serum glutamic oxaloacetic and glutamic pyruvic transaminases. Am. J. Clin. Path., 28: 56-61.

Sankara, S.; Abraham, G.; Soundararajan, P.; Darasekaran, V. and Padama, G. (2005): Parathyroid hormone and biochemical profile in chronic kidney disease patients in South India. Hemodial. Int., 9: 63-70.

Segal, A.; Ellis, J. and Baumgartner, B. (2008): Dialysis to determine the prevalence of thrombocytopenia and heparin induced thrombocytopenia. Manual on Contrast Media 3: 498504.

Tietz, N.W. (1986): "Textbook of clinical chemistry" Saunders, E.B. Co. London Philadelphia. P: 796.

Willem, M. W.; Marlies, N.; Friedo, W. D.; Elisabeth, W. B.; Raymond, T. K.; Johanna, C. K. and Ronald, B. G. (2011): Full loss of residual renal function causes higher mortality in dialysis patients finding from amarginal structural model. Nephrolo. Dial. Transplant., 10:1093.

\section{ARABIC SUMMERY}

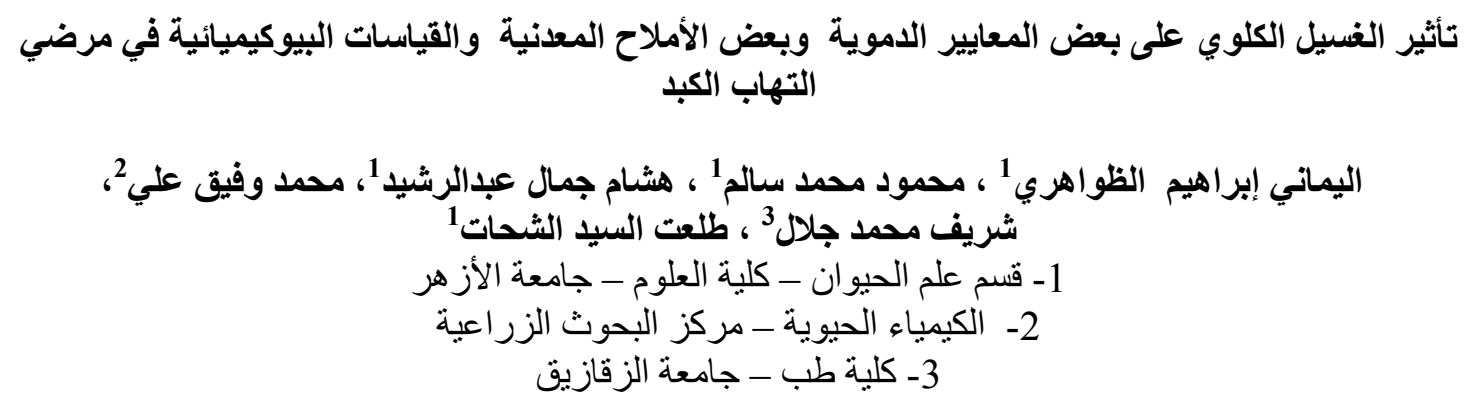

الدراسة الحالية توضح تأثير الغسيل الكلوي علي بعض المعايير الدموية وبعض الأملاح المعدنية

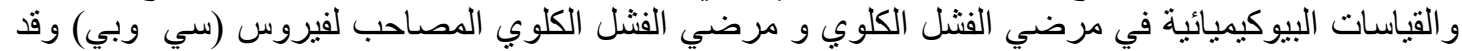

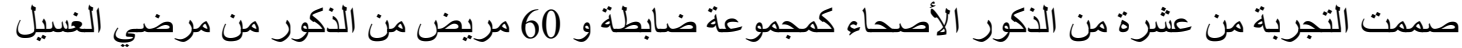

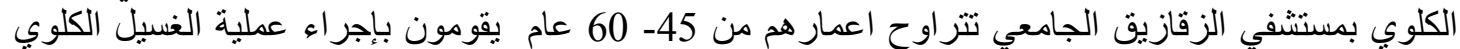

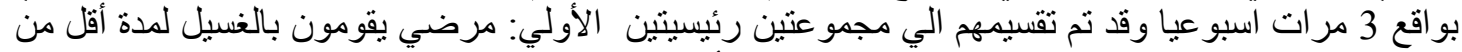

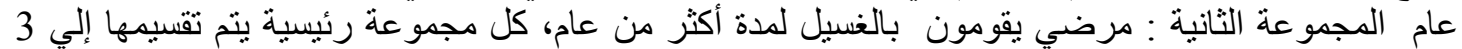

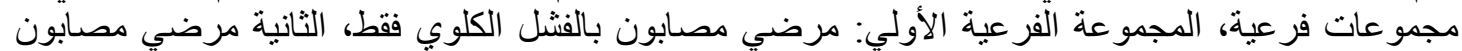

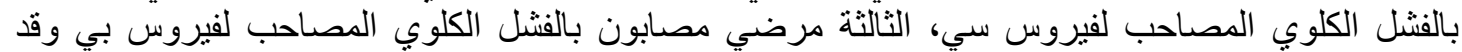

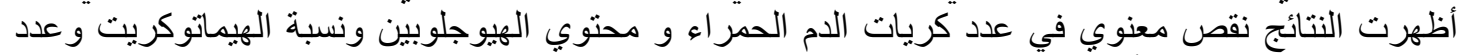

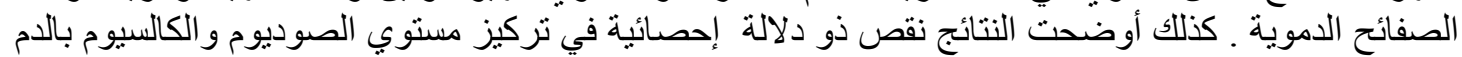

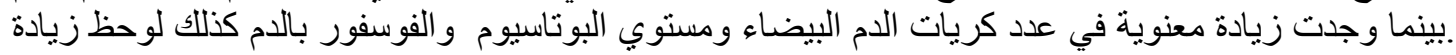
معنوية في مستوي نشاط إنزيمات الكبد ) ALAT, ASAT) بالكصل. 